\title{
Correlation between Generation Times and L-Threonine Dehydratase Activities in Isoleucine Revertants of Serratia marcescens
}

\author{
By S. KOMATSUBARA, M. KISUMI AND I. CHIBATA \\ Research Laboratory of Applied Biochemistry, Tanabe Seiyaku Co., \\ I6-89 Kashima-3-chome, Yodogawa-ku, Osaka 532, Japan
}

(Received 9 September 1975; revised 9 January 1976)

\section{INTRODUCTION}

We have previously described the regulation of isoleucine-valine biosynthesis in Serratia marcescens (Kisumi, Komatsubara \& Chibata, I97I $a$ ). In S. marcescens and other enteric bacteria, isoleucine biosynthesis is regulated by feedback inhibition and repression of L-threonine dehydratase (Umbarger, 1973). L-Threonine dehydratases from various sources were purified and their in vitro properties investigated (Umbarger, 1969). All the enzymes possessed two allosteric properties in common: feedback inhibition by isoleucine; and activation by valine or leucine. Mutants having feedback-resistant enzymes accumulated isoleucine in the medium, thus providing physiological confirmation of the feedback inhibition of L-threonine dehydratase (Kisumi et al., I972; Reh \& Schlegel, 1969). However, little is known about the nature of feedback control of L-threonine dehydratase in vivo. This paper describes the correlation between generation times and enzyme activities in revertants derived from mutants of $S$. marcescens, lacking L-threonine dehydratase, which sheds some light on the in vivo feedback control of this enzyme.

\section{METHODS}

Bacteria. The bacterial strains used were $S$. marcescens strain I (wild type; Kisumi, 1962); an isoleucine auxotroph, strain 621 (L-threonine dehydratase-deficient) derived from strain I ; 20 spontaneous revertants derived from strain $62 \mathrm{I}$ by the method of Kisumi, Komatsubara \& Chibata (1973); and strain 149 (L-threonine dehydratase-deficient) derived from strain ARI30-I, an $\alpha$-aminobutyric acid-resistant mutant of $S$. marcescens strain I (Kisumi et al. I973).

Generation time. Bacteria were grown in minimal medium (MM) (Davis \& Mingioli, I950) modified by omitting citrate and increasing the glucose concentration to $0.5 \%(\mathrm{w} / \mathrm{v})$. Cultures in the late exponential growth phase were diluted into $500 \mathrm{ml}$ shaking flasks containing $150 \mathrm{ml}$ of the same medium. The initial absorbance at $660 \mathrm{~nm}$ was $0.05\left(2.5 \times 10^{8}\right.$ bacteria $\left.\mathrm{ml}^{-1}\right)$. Cultures were incubated at $30^{\circ} \mathrm{C}$ with reciprocal shaking ( $140 \mathrm{rev} . / \mathrm{min}$, $8 \mathrm{~cm}$ stroke) and their absorbances determined at hourly intervals. Bacteria grew exponentially until their absorbance reached $0 \cdot 6$. Generation times were calculated from the slopes of the linear portions of semi-log plots of the growth data.

Enzyme assays. Cell-free extracts were prepared from exponentially-growing bacteria. L-Threonine dehydratase and acetohydroxy acid synthetase activities were determined as described previously (Kisumi et al., I97I c). 


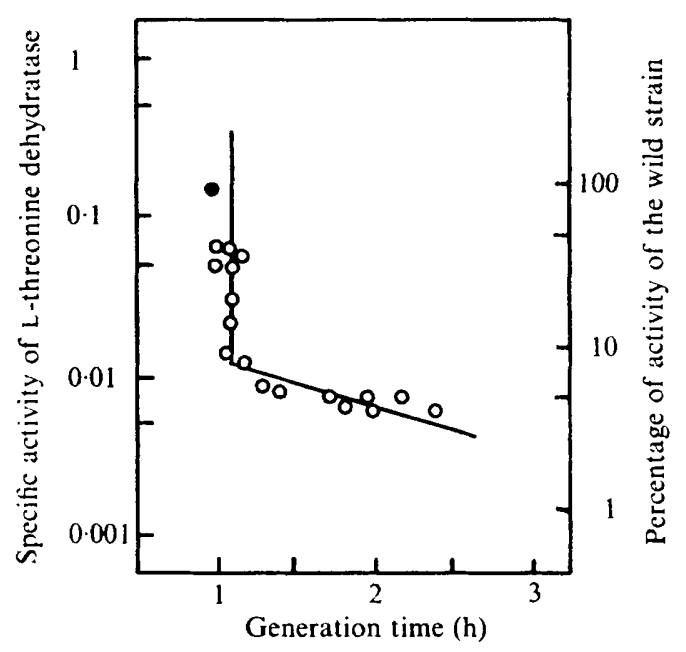

Fig. 1. Correlation between generation times and L-threonine dehydratase activities in the revertants derived from strain $621(\bigcirc)$ and in strain 1 (wild type) (O), cultured in minimal medium. Specific activity is expressed as $\mu \mathrm{mol} \alpha$-ketobutyrate formed (mg protein) ${ }^{-1} \mathrm{~min}^{-1}$.

\section{Table I. Generation times and isoleucine-valine biosynthetic enzymes of revertants derived from strain $62 \mathrm{I}$}

Enzyme activities were assayed using extracts prepared from bacteria cultured in minimal medium (MM). For growth of strain $62 \mathrm{I}$, the minimal medium was supplemented with $\mathrm{IO}^{-9} \mathrm{M}$ L-isoleucine. The specific activities are expressed as $\mu \mathrm{mol}$ product formed (mg protein) ${ }^{-1} \mathrm{~min}^{-1}$.

\begin{tabular}{|c|c|c|c|c|c|c|}
\hline \multirow[b]{3}{*}{ Strain } & \multirow{2}{*}{\multicolumn{2}{|c|}{ Generation time (h) }} & \multicolumn{3}{|c|}{ L-threonine dehydratase } & \multirow{3}{*}{$\begin{array}{c}\text { Specific } \\
\text { activity of } \\
\text { acetohydroxy } \\
\text { acid } \\
\text { synthetase }\end{array}$} \\
\hline & & & \multirow[b]{2}{*}{$\begin{array}{l}\text { Specific } \\
\text { activity }\end{array}$} & \multicolumn{2}{|c|}{$\begin{array}{c}\text { Inhibition }(\%) \text { by } \\
\text { L-isoleucine: }\end{array}$} & \\
\hline & MM & $\begin{array}{l}\mathbf{M M}+10^{-\mathbf{3}} \mathbf{M} \\
\text { L-isoleucine }\end{array}$ & & $3 \times 10^{-4} M$ & $10^{-3} \mathrm{M}$ & \\
\hline Wild type I & $I \cdot O$ & $I \cdot O$ & 0.15 & 68 & 95 & 0.053 \\
\hline $\begin{array}{l}\text { Isoleucine } \\
\text { auxotroph } 62 \mathrm{I}\end{array}$ & $\infty$ & $\mathbf{I} \cdot \mathbf{I}$ & ND & - & - & 0.042 \\
\hline Revertants $621-7$ & $I \cdot I$ & $\mathbf{I} \cdot \mathbf{I}$ & 0.045 & 68 & 92 & $0.06 \mathrm{I}$ \\
\hline $62 I-26$ & $I \cdot I$ & $\mathbf{I} \cdot \mathbf{I}$ & 0.019 & 3 & 25 & 0.10 \\
\hline $62 I-8$ & $1 \cdot 2$ & $I \cdot I$ & 0.014 & 25 & 52 & $0 \cdot 10$ \\
\hline $621-17$ & $2 \cdot 4$ & $\mathbf{I} \cdot \mathbf{I}$ & 0.006 & 2 & 10 & $0 \cdot 14$ \\
\hline
\end{tabular}

ND, Not detected.

\section{RESULTS AND DISCUSSION}

The 20 spontaneous revertants were isolated from colonies of different sizes on a minimal agar culture of strain $62 \mathrm{I}$. Their generation times and L-threonine dehydratase activities in minimal medium were measured and are shown in Fig. I. Nine revertants with similar generation times $(\mathrm{I} \cdot \mathrm{O}$ to $\mathrm{I} \cdot \mathrm{I} \mathrm{h})$ to the wild type possessed L-threonine dehydratase activities which were greater than $10 \%$ of that of the wild type. Six other revertants grew more slowly in minimal medium (generation time less than $\mathrm{I} \cdot 5 \mathrm{~h}$ ), but grew at the same rate as the wild type in minimal medium plus isoleucine. These revertants had enzyme activities which were less than $10 \%$ of that of the wild type. It was possible that the apparent low levels of L- 
threonine dehydratase might be due to instability of the enzyme in cell-free extracts, but similar results were obtained with toluene-treated bacteria. In the revertants which had less than $10 \%$ of the $\mathrm{L}$-threonine dehydratase activity of the wild type, the enzyme was made relatively insensitive to feedback inhibition by isoleucine to varying extents (Table $I$ ). Such revertants were derepressed for acetohydroxy acid synthetase, the second isoleucinevaline biosynthetic enzyme, suggesting that the intracellular isoleucine pools were limiting for normal growth; in other words, isoleucine biosynthesis is not subject to any feeedback control in these strains. Thus, $10 \%$ of the wild-type L-threonine dehydratase activity in the revertants allows sufficient in vivo production of $\alpha$-ketobutyrate from threonine for normal growth.

To confirm that this low level of L-threonine dehydratase permits normal growth of the wild type in minimal medium, similar experiments were made with revertants of strain I49, an isoleucine auxotroph which had constitutive levels of the isoleucine-valine biosynthetic enzymes other than L-threonine dehydratase. As expected, an L-threonine dehydratase activity of more than $10 \%$ of that of the wild type was necessary for growth at the same rate as that of strain ARI30-I, the parent strain I49 (unpublished results).

Thus, based on in vitro assays, the wild type possessed an L-threonine dehydratase activity ro times greater than the minimum necessary for normal growth. This suggests that about $90 \%$ of this activity should be feedback-inhibited by isoleucine to avoid overproduction of the amino acid. This amount of in vivo feedback inhibition would be very severe, although repression may be relaxed. Mutants of $S$. marcescens resistant to $\alpha$-aminobutyric acid, which were derepressed for L-threonine dehydratase and the other isoleucine-valine biosynthetic enzymes, did not accumulate isoleucine in a medium containing L-threonine (Kisumi, Komatsubara \& Chibata, I97I b). Isoleucine hydroxamate-resistant mutants with a feedback-resistant L-threonine dehydratase produced large amounts of isoleucine from L-threonine (Kisumi et al., I971d). These facts also support the idea that feedback inhibition rather than repression acts as the primary mechanism for the control of the isoleucine biosynthesis.

We are grateful to T. Takayanagi, senior manager of the Research and Development Division of this company, for encouragement. We also thank F. Murakami and M. Ashibe for technical assistance.

\section{REFERENCES}

Davis, B. D. \& Mingroli, E. S. (1950). Mutants of Escherichia coli requiring methionine or vitamin $\mathrm{B}_{12}$. Journal of Bacteriology 60, 1 7-28.

KIsUmI, M. (1962). Studies on the isoleucine fermentation. I. Screening of organisms and investigation of cultural conditions. Journal of Biochemistry 52, 390-399.

Kisumi, M., Komatsubara, S. \& Chibata, I. (197I $a$ ). Multivalent repression and genetic derepression of isoleucine-valine biosynthetic enzymes in Serratia marcescens. Journal of Bacteriology 107, 824-827.

Kisumi, M., Komatsubara, S. \& Chibata, I. (I97I $b$ ). Valine accumulation by $\alpha$-aminobutyric acid-resistant mutants of Serratia marcescens. Journal of Bacteriology 106, 493-499.

Kisumi, M., Komatsubara, S. \& Chibata, I. (I973). Leucine accumulation by isoleucine revertants of Serratia marcescens resistant to $\alpha$-aminobutyric acid: lack of both feedback inhibition and repression. Journal of Biochemistry 73, 107-115.

Kisumi, M., Komatsubara, S., Sugrura, M. \& Chibata, I. (I971 c). Isoleucine hydroxamate, an isoleucine antagonist. Journal of Bacteriology ro7, 74I-746.

Kisumi, M., Komatsubara, S., Sugiura, M. \& Chibata, I. (197 I $d$ ). Properties of isoleucine hydroxamateresistant mutants of Serratia marcescens. Journal of General Microbiology 69, 291-297.

Kisumi, M., Komatsubara, S., Sugiura, M. \& Chibata, I. (1972). Isoleucine accumulation by regulatory mutants of Serratia marcescens: lack of both feedback inhibition and repression. Journal of Bacteriology г10, 76I-763. 
ReH, M. \& Schlegel, H. G. (1969). The biosynthesis of isoleucine and valine in Hydrogenomonas HI6. Archiv für Mikrobiologie 67, $110-127$.

UMBARGER, H. E. (1969). Regulation of the biosynthesis of the branched-chain amino acids. Current Topics in Cellular Regulation $\mathrm{x}, 57-76$.

UMBARGER, H. E. (1973). Genetic and physiological regulation of isoleucine, valine and leucine formation in the Enterobacteriaceae. In Genetics of Industrial Microorganisms (Bacteria), pp. 195-218. Edited by Z. Vanēk, Z. Hoštáek and J. Gudlín. Prague: Academia. 